\title{
Treatment of Residues from the Copper Industry with an Alternative Approach for Electric Furnace Slag
}

\author{
Stephan R. Steinacker and Juergen Antrekowitsch
}

Christian Doppler Laboratory for Optimization and Biomass Utilization in the Recycling of Heavy Metals, Chair of Non-Ferrous Metallurgy, Montanuniversitaet Leoben, Leoben, Austria

Received May 4, 2017; accepted May 15, 2017; published online June 12, 2017

\begin{abstract}
Today's copper industry sees itself confronted with a variety of different residues and by-products. This situation can be explained by the decreasing content of copper in the primary ore concentrate and the multitude of further downstream processes and applications. This work aims at giving an overview of the different residues that derive from the primary as well as the secondary copper industry and highlights the potential in eastern and southeastern Europe. The core part of this article describes different recycling and recovery methods, which can be split into two main categories. The direct treatment generally consists of a remelting step which builds on a detailed chemical analysis and aims at the preservation of the contained alloying elements. In contrast to the direct option, the conventional recycling consists of several process steps which gradually increase the purity and quality of the material.

The description of a new approach for the treatment of electric furnace slag concludes the considerations concerning the different residues. While the introduction of primary copper smelting slag into an electric furnace displays a commonly applied procedure which leads to a marketable product, legislative as well as environmental restrictions may restrict this opportunity in the near future. As a result, a pyrometallurgical approach that uses pig iron as a reducing agent aims at lowering the contained heavy metal content in the slag and hence at guaranteeing the required marketability.
\end{abstract}

Keywords: Copper recycling, Residues, Copper slag, Pig iron, Reduction

\footnotetext{
S. R. Steinacker $(\bowtie)$
}

Christian Doppler Laboratory for Optimization and Biomass

Utilization in the Recycling of Heavy Metals,

Chair of Non-Ferrous Metallurgy,

Montanuniversitaet Leoben,

Franz-Josef-Strasse 18,

8700 Leoben, Austria

stephan.steinacker@unileoben.ac.at
Aufarbeitung von Rückständen aus der Kupferindustrie mit einem alternativen Ansatz für Elektroofenschlacke

Zusammenfassung: Die heutige Kupferindustrie sieht sich mit einer Vielzahl an unterschiedlichen Reststoffen und Nebenprodukten konfrontiert. Diese Tatsache lässt sich vor allem auf den abnehmenden Kupfergehalt im Erzkontentrat und die Verschiedenartigkeit der weiterverarbeitenden Prozesse zurückführen.

Ein Ziel der vorliegenden Arbeit liegt darin, unterschiedliche Reststoffe aus der primären und sekundären Kupferindustrie näher zu beschreiben, wobei ein Fokus auf dem vorhandenen Potenzial im ost- und südosteuropäischen Raum liegt. Die direkte Aufarbeitung besteht grundsätzlich aus einem Aufschmelzschritt, welcher eine genaue chemische Analyse verlangt und auf einen möglichst geringen Verlust der vorhandenen Legierungselemente abzielt. Im Gegensatz dazu umfasst das konventionelle Recycling eine breite Prozesskette, über welche die Qualität und die Reinheit des Werkstoffs kontinuierlich zunehmen.

Abschließend soll eine alternative Methode für die Aufarbeitung von Schlacke aus dem Elektroofen beschrieben werden. Während der Einsatz von primärer Kupferschlacke in diesem Aggregat einen klassischen Prozess zur Kupferrückgewinnung darstellt, welcher darüber hinaus zu einem absatzfähigen Produkt führt, könnten legislative sowie umwelttechnische Restriktionen zu einem abrupten Ende der bewussten Nutzung führen. Der in dieser Arbeit beschriebene pyrometallurgische Ansatz versucht, den Schwermetallgehalt der Schlacke weiter zu senken, um so deren Marktfähigkeit weiterhin zu gewährleisten.

Schlüsselwörter: Recycling von Kupfer, Reststoffe, Kupferschlacke, Roheisen, Reduktion

\section{Introduction}

After iron and aluminum, copper represents the third-most produced metal on a global basis with an annual amount 


\begin{tabular}{|c|c|c|c|c|}
\hline Cu Production & Austria & Bulgaria & Serbia & Slovakia \\
\hline Primary [t/a] & - & 305.000 & 33.000 & - \\
\hline Secondary [t/a] & 60.000 & 55.000 & 1.000 & 23.300 \\
\hline Total [t/a] & 60.000 & 360.000 & 34.000 & 23.300 \\
\hline
\end{tabular}

\begin{tabular}{|llllll}
\hline \multicolumn{1}{|l}{$\begin{array}{l}\text { TABLE } 2 \\
\text { Excerpt of relevant copper smelting companies in the ESEE region [6-11] }\end{array}$} & & \\
\hline Country & Austria & Bulgaria & Bulgaria & Serbia & Slovakia \\
\hline Company & $\begin{array}{l}\text { Montanwerke Brix- } \\
\text { legg }\end{array}$ & $\begin{array}{l}\text { Assarel-Medet } \\
\text { Mine }\end{array}$ & Pirdop Smelter & $\begin{array}{l}\text { 2 Mines, Bor } \\
\text { Smelter }\end{array}$ & Kovohuty, a.s. \\
\hline Owner & UMCOR AG & Assarel-Medet JSC & Aurubis AG & RTB Bor Group & UMCOR AG \\
\hline
\end{tabular}

of around 21.1 Mio. $t$ considering the copper content of the world mine production in the year 2015 [1]. While the primary production from sulfidic and oxidic ores still represents the central production route, recycling methods constantly gain importance. In addition to the valuable metal copper, residues and by-products display a broad variety of chemical elements which can improve the economic feasibility of different secondary processes [2].

This work concentrates on copper companies and sources from eastern and southeastern Europe (ESEE). After giving an overview of the potential in this region, different residues from the copper industry can be investigated. Subsequently, adequate recycling techniques are presented, which lead to a classification into direct as well as conventional approaches. Their common goal is represented by an efficient recovery of copper and the production of a high-purity material. In addition, by-elements, such as zinc, lead, and arsenic, are also considered. On the one hand, these display a contamination within the raw material, while, on the other hand, their recycling potential due to the relatively high share can lead to a better overall profitability. Depending on the chemical analysis of the input materials, adequate techniques need to be found for different types of residues [3].

The importance of efficient recycling methods is underlined with an example from recent research efforts. Ferro silicate slag displays a significant by-product in the primary copper production cycle which is commonly sold and applied in the road construction and similar sectors. In order to lower the amount of remaining metals, a reduction approach with pig iron is applied. By comparing the final share and especially considering copper itself as well as zinc, considerations concerning the further marketability can be obtained.

\section{Copper in the ESEE Region}

Different metals, such as lead, zinc, and different ferroalloys, play an important role in the eastern and southeastern parts of Europe (ESEE). For the year 2014, the U.S. Geological Survey [4] considers the worldwide copper production and also states relevant data for the ESEE region. Table 1 lists the annual smelting capacities for relevant pro- ducing countries in the ESEE region. These include Austria and Slovakia, which only work in the secondary recycling business, as well as Bulgaria and Serbia, which also provide a primary production route. In the year 2014, the total amount of produced copper from smelting processes in the ESEE region reaches $477.3 \mathrm{t}[4,5]$.

Based on the results from Table 1, different copper producing companies in the ESEE can be determined. Similarly to the preceding example, Table 2 focuses on actual copper smelters in the mentioned area. Montanwerke Brixlegg represents the only copper-producing company in Austria and concentrates on the recycling of different types of scrap. The firm belongs to Swiss UMCOR AG, which also constitutes the owner of the Slovakian copper recycler Kovohuty in the northern part of the country. In Serbia, RTB Bor Group owns two mines as well as a smelting facility in the eastern part, which is why an integrated production concept can be applied. In contrast, the mines and the smelter belong to different companies in Bulgaria. On the one hand, Assarel-Medet owns a mine complex situated around $40 \mathrm{~km}$ north of Pirdop, and, on the other hand, the German-owned Aurubis AG runs a smelting facility [6-11].

While the production of metallic copper displays the principle target of the different companies, a certain focus also has to be set on the resulting residues. Sect. 3 aims to classify different types of by-products and scrap, and Sect. 4 presents corresponding recovery techniques.

\section{Residues from the Copper Industry}

Low-grade residues deriving from the copper metallurgy can generally be split into different groups such as slag, dust, dross and sludge. In addition, high quality materials like alloying scrap or various types of shredder also accumulate and need an adequate treatment. Table 3 sums up possible residues which have to be considered for a secondary recycling method and which display a large range in copper content $[2,12-15]$.

In general, the various materials can be split into two main categories - a metallic as well as a non-metallic fraction. Metallic residues usually display a high content in copper and do not need an extensive treatment. On the other hand, non-metallic remainders include slags, 


\begin{tabular}{|ll}
\hline $\begin{array}{l}\text { TABLE } 3 \\
\text { Different residues from the copper industry with cor- } \\
\text { responding Cu content [2, 12-15] }\end{array}$ \\
\hline Material & $\% \mathrm{Cu}$ \\
\hline Alloying Scrap & $36-60$ \\
\hline Non-ferrous Shredder & $10-60$ \\
\hline Slag & $5-50$ \\
\hline Dross & $10-50$ \\
\hline Sludge & $1-40$ \\
\hline Dust & $1-30$ \\
\hline WEEE & $7-20$ \\
\hline
\end{tabular}

\begin{tabular}{|llll}
\hline \multicolumn{4}{|l}{$\begin{array}{l}\text { TABLE } \\
\text { Chemical distribution of the metallic fraction in } \\
\text { printed circuit boards [19] }\end{array}$} \\
\hline Element & {$[\mathrm{ppm} / \%]$} & Min & Max \\
\hline $\mathrm{Ag}$ & $\mathrm{ppm}$ & 639 & 3000 \\
\hline $\mathrm{Au}$ & $\mathrm{ppm}$ & 70 & 566 \\
\hline $\mathrm{Pd}$ & $\mathrm{ppm}$ & 75 & 124 \\
\hline $\mathrm{Cu}$ & $\%$ & 3.0 & 25.0 \\
\hline $\mathrm{Fe}$ & $\%$ & 4.5 & 7.7 \\
\hline $\mathrm{Zn}$ & $\%$ & 1.4 & 1.5 \\
\hline $\mathrm{Ni}$ & $\%$ & 0.2 & 1.1 \\
\hline $\mathrm{Pb}$ & $\%$ & 1.0 & 2.2 \\
\hline $\mathrm{Al}$ & $\%$ & 2.8 & 7.3 \\
\hline
\end{tabular}

dust, and sludge from copper-producing companies which only possess a limited amount of valuable metals. These residues display an oxidic behavior, which is why an adequate pyrometallurgical treatment has to be found and applied. Typical materials within a market with a continuously rising importance include different types of dust slags from the brass industry, and sludge from the galvanic sector $[2,16,17]$.

In addition to the mentioned categories, waste electrical and electronic equipment (WEEE) has become more and more important recently. Generalizations with regard to the chemical composition are hard to make, since this material constitutes a relatively new input material on the recycling side. Printed circuit boards for example offer an excellent opportunity for an economic recovery method due to their elevated precious metal content. Generally, the three categories of metal, plastics, and ceramics can be split by a ratio of 40:30:30. Table 4 lists the distribution of relevant elements within the metallic fraction and underlines the potential for a further recycling method [18-20].

Since waste electrical and electronic equipment often displays an inhomogeneous composition, a detailed analysis and preparation are at the center of successful recycling. The contamination based on organic or halogen-containing compounds represents a common problem which remains at the center of investigation concerning recovery methods. Due to the elevated amount of copper as well as precious metals, this area will gain further importance in the near future $[18,21]$.

\section{Recycling Methods for Different Residues}

Possible recycling methods for the broad variety of residues include a direct as well as a so called conventional option. The direct recycling of scrap from the copper industry generally displays a remelting of the input materials. Since no refining electrolysis takes place, a significant amount of energy can be saved. Yet, no treatment for removing precious metals, such as silver or gold, can be applied. While direct methods show the advantage of keeping alloying elements, such as tin or zinc, within the product, lower-grade scrap as well as materials with higher quality requirements have to undergo the conventional treatment $[12,22]$.

\subsection{Direct Method}

The direct recycling can be split into two different approaches. First, the direct method without any further treatment qualifies as the most energy-saving and simple process, while, second, an additional fire refining step can help to achieve a better product quality without an excessive input of further energy.

\subsubsection{Direct Recycling without Fire Refining}

The direct recycling of residues from the copper industry constitutes a relatively simple process from a metallurgical point of view. Certain details, however, have to be considered. The main source for losses can be explained by the formation of dross during the pyrometallurgical treatment, which derives from the reaction of the liquid metal with the atmosphere and the refractory material. The evaporation of elements with a high vapor pressure such as zinc are another factor. Apart from the amount and the function of the contained alloying elements, the quality of the produced copper product can be explained by the contained amount of hydrogen and oxygen. The latter element enforces a brittle behavior, which leads to a lower electric conductivity, while hydrogen causes porosity and hence a lower lifespan. Due to the mentioned effects, strict specifications for $\mathrm{O}_{2}$ as well as $\mathrm{H}_{2}$ are deducted. Methods for reducing their role and quantity include the use of adequate refractories, low melt temperatures, short treatment times, and the application of deoxidation- as well as covering products. Induction furnaces display the most commonly used vessel for the direct recycling of copper residues. The copper content of the input materials should be above $97 \%$ in order to prevent the formation of slag, which can have a negative impact on the tapping holes of the furnace. As a consequence, the furnaces often display a slightly reducing atmosphere $[12,22$, 23].

\subsubsection{Direct Recycling with Fire Refining}

In contrast to a treatment without further refining, this pyrometallurgical concept offers the option for treating residues with a lower copper content. While typical values only reach a $\mathrm{Cu}$ share of around $90 \%$, alloying elements are not desired because the refining step results in their 


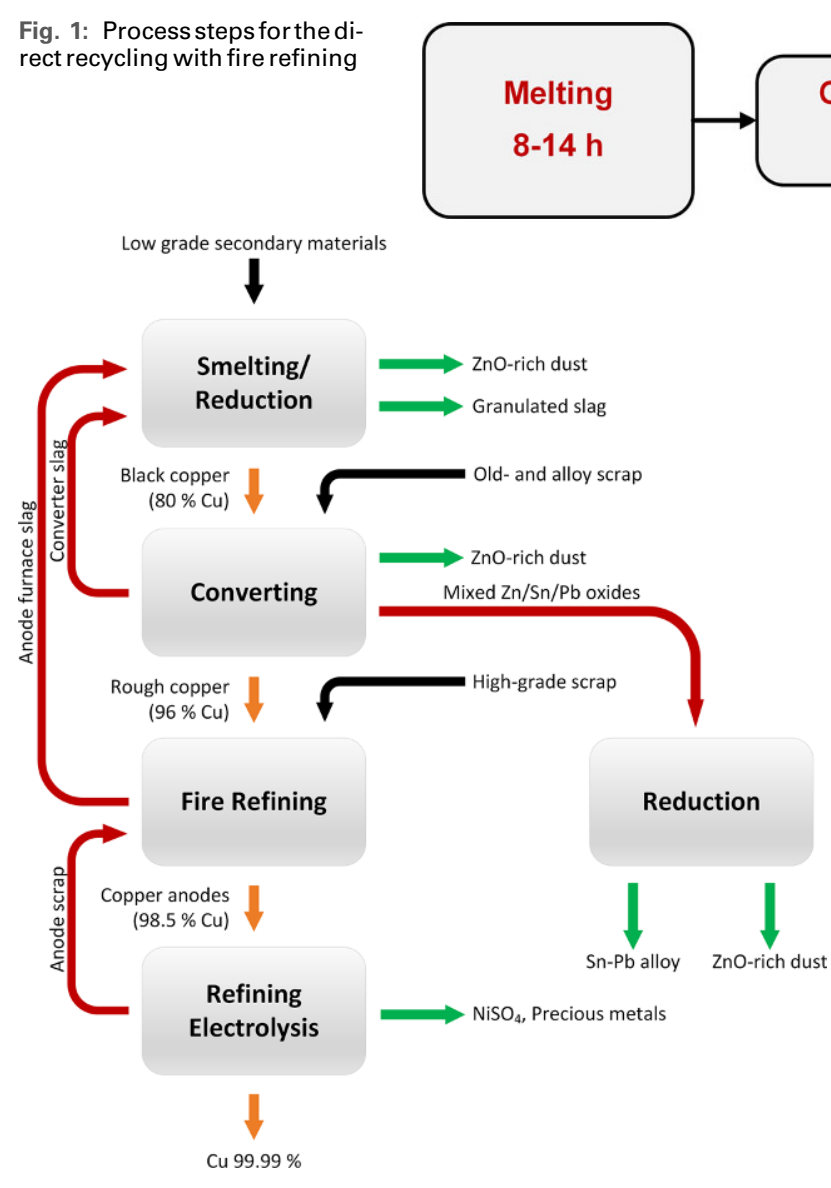

Fig. 2: Process scheme for the conventional recycling method of residues from the copper industry [26]

removal. Since the principles are similar to the primary anode production, the vessels also show the same buildup. Fig. 1 highlights the different treatment steps with the needed amount of time. These include the melting, an oxidation, the subsequent reduction, the foundry as well as a rolling plant $[24,25]$.

Heating and melting the charged material displays the treatment step that requires the highest amount of time and energy. Typical vessels which often use gas burners and own a capacity of around $500 \mathrm{t}$ include rotary and reverberatory furnaces. The slag that forms during the melting step has to be removed before refining. Subsequently, oxygen is introduced into the melt in order to achieve a total amount of around $1-1.2 \%$. The most common elements that occur in addition to the desired copper include lead, tin, zinc, iron, nickel, antimony, and arsenic as well as sulfur. By applying several refining steps, their influence can be further reduced. Since the maximum amount of oxygen must not exceed 500 ppm for many practical applications, the dissolved $\mathrm{O}_{2}$ has to be removed afterwards. In order to achieve a successful oxidation, hydrogen- and carbon carriers can be used. After this reduction, the melt can be cast into wires or anodes for a further refining in an electrolysis, which leads to a further increase in product purity and quality $[24,25]$.
The main advantage of direct recycling lies in the fast treatment of the regarded input materials and the achieved energy savings. The corresponding cost reduction constitutes another positive effect, although the lower revenues due to the comparably reduced product quality almost annihilate this advantage. In contrast, the formation of new residues, such as slags and dust, displays a significant disadvantage of the direct methods. Since adequate technologies are often not available at the designated production sites, each of the resulting residues represents an additional copper loss. Furthermore, the recovery of precious metals cannot be achieved, which is why the described methods do not qualify for the treatment of materials rich in silver or gold $[2,12,22]$.

\subsection{Conventional Recycling Method}

Economic reasons promote a direct treatment of the different residues. The conventional method offers an option for treating a broad variety of input materials with very low amounts of the desired metal. Due to the noble behavior of copper, the process bases on the primary production route. While sulfur - a very important element in the ore - only plays a subordinate role, the most significant by-metals include lead, zinc, tin, iron, and nickel. In addition, a focus is set on the recovery of precious metals such as gold and silver, which preferably accumulate in the anode slime. As a result, modern copper smelters do not only deal with $\mathrm{Cu}$ but specialize in a so called multi-metal recycling [2, 22].

The conventional recycling method for copper residues can be split into four main process steps. Fig. 2 displays this procedure, which starts with a smelting step, after which the black copper needs to be converted. Following the fire refining in an adequate furnace, a refining electrolysis further increases the product quality similarly to the primary production route. The black arrows in the image symbolize different types of residues, which gradually provide a higher copper content according to the process flow. Depending on the type of material, the share of $\mathrm{Cu}$ can be as low as $1 \%$, while typical contents reach $40 \%$. The main fraction comprises of oxidic materials, while sulfides, sulfates, carbonates, and more complex structures can also occur. The orange arrows represent the copper flow, while the green arrows constitute desired by-products with a relatively high quality, which therefore commonly represent marketable materials. The red loops describe internal process residues with a significant share of copper or other valuable metals, which are either fed back into a preceding step or recycled in an additional reduction vessel. Typical examples include internal dust and slags from the fire refining as well as the converting steps [26]. 


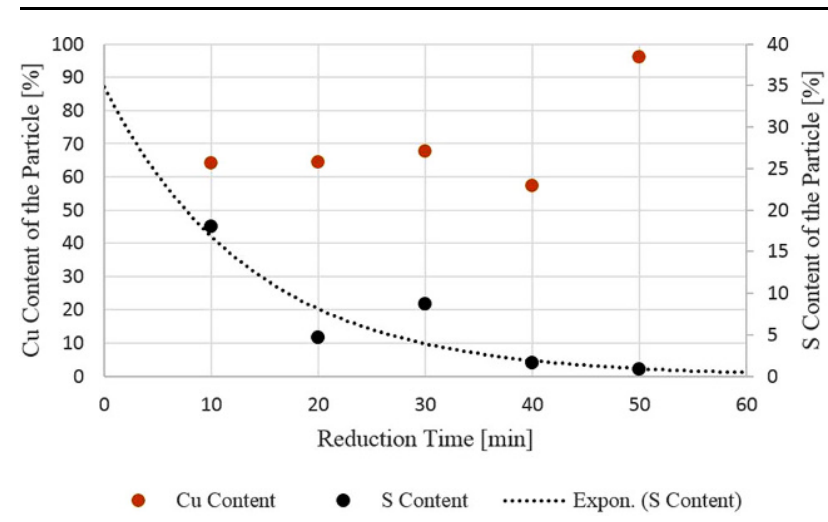

Fig. 3: Copper and sulfur content of the resulting particles after the treatment

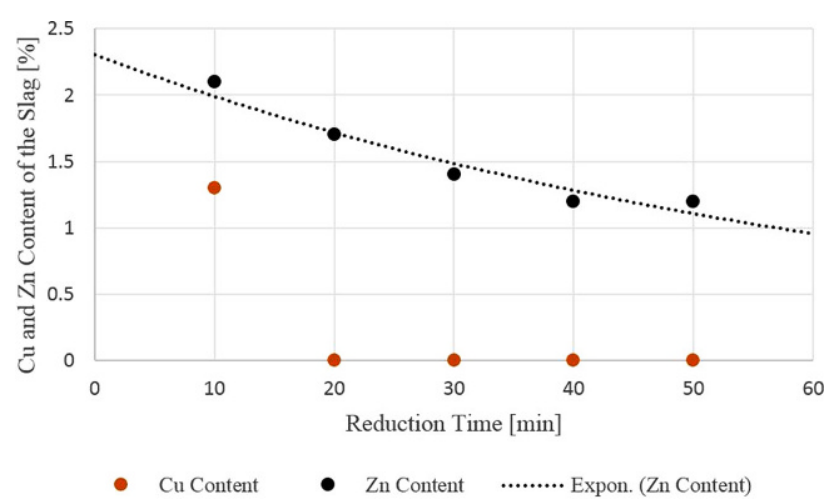

Fig. 4: Copper and zinc content of the resulting slag after the treatment

Typical vessels for the smelting and reduction step include electric furnaces and bath melting reactors. In addition, top-blown rotary converters and submerged lance systems find their application in this field. Similarly to the primary copper production, Peirce-Smith converters can be used for the second step. Yet, the amount of additional scrap that can be charged reaches a significantly lower value. This fact can be explained by the absence of sulfur, which causes a less exothermic reaction. Vessels for the fire refining and the electrolysis display the same buildup as in the primary production. While the process parameters correlate, the input materials lead to a higher share of nickel, which is why the electrolyte has to be cleaned from time to time. By performing an adequate process step, the nickel can be selectively won and subsequently be sold as sulfate $[2,27]$.

\section{New Approach for Electric Furnace Slag}

The pyrometallurgical treatment of the ferro silicate slag from primary smelting vessels in an electric furnace represents a commonly applied method. Copper losses in the slag can generally be split into two categories. First, the physical fraction consists of mechanically trapped solids, while, second, chemically dissolved particles constitute another possibility. Before the electric furnace, the fayalite slag shows a share of around $65-80 \%$ in mechanical losses.
Due to the reducing conditions and almost no movement in the electric furnace, however, this percentage can be lowered to a ratio of approximately $25 \%[2,3]$.

\subsection{Experimental Set-up}

In order to guarantee the further marketability of the fayalite slag and to recover as much of the valuable metals as possible, an additional process step may offer a solution. A detailed investigation in the scanning electron microscope shows a sulfidic behavior of the remaining copper particles, which is why a successful reduction with typically applied carbon cannot be achieved. As a possible alternative, pig iron can act as a reducing agent in order to lower the amount of remaining copper in the ferro silicate slag. Enthalpy lines in the Richardson Ellingham Diagram show a close position of the copper as well as the iron sulfide lines, which is why the thermodynamic feasibility should be investigated in several experiments.

Concerning the experimental build-up, $0.5 \mathrm{~kg}$ of fayalite slag are mixed with an overstoichiometric amount of pig iron. The additional share of $3.79 \%$ in the material shows a positive impact on the overall reducibility. Several trials are performed at a chosen process temperature of $1200^{\circ} \mathrm{C}$, while the reduction time represents the most important parameter that is varied. After the designated time, the slag samples are quenched and prepared for phase as well as chemical analyses in the scanning electron microscope.

\subsection{Experimental Results}

Different results can be derived from the experimental copper slag reduction series. The most important factors include the reduction grade of the metallic particles as well as their grain size, the influence of the treatment time, and the chemical composition of the two resulting fractions the fayalite slag and the copper particles.

Fig. 3 displays the copper and the sulfur content of a variety of metallic particles in relation to the chosen reduction time. As can be observed, the amount of copper increases slightly with a longer treatment, while the share of sulfur drops significantly. As a result, almost sulfur-free particles are achieved. The relatively low copper content of the particles can be explained by the overstoichiometric amount of pig iron, which leads to a copper-iron alloy.

In addition to the behavior of the metallic particles, the resulting slag itself also needs to be investigated Fig. 4 . sums up relevant information concerning the copper and the zinc content of the ferro silicate depending on the treatment time. A copper share below the detection limit of $0.1 \%$ in the scanning electron microscope represents the main result. Hence, the reduction with pig iron constitutes a feasible approach for the treatment of the contained copper. In addition to effects based on reaction kinetics, a possible reaction at solid state can also show a positive impact on this reaction as the process favorably takes place at a low temperature. In relation to the achievable copper content, short treatment times suffice, while the result for zinc - an- 
other important metal in the slag that has to be considered - varies significantly. Even after $50 \mathrm{~min}$, its share remains at around $1.3 \%$, which prevents the produced iron silicate slag from being used for industrial applications. In a next step, the process will have to be adapted in order to lower the total zinc content. Additionally, other elements, such as lead and arsenic, will have to be dealt with in order to produce a marketable fayalite slag. Therefore, different mixtures of reducing agents can be applied while keeping a focus on pig iron.

\section{Conclusion and Outlook}

The investigation of different copper smelters in eastern and southeastern Europe shows a range of primary as well as secondary production sites. By considering distinct types of by-products that accumulate during the primary production and focusing on various residues, adequate recycling techniques can be applied.

While direct approaches only require a low amount of energy, the conventional recycling method offers an excellent opportunity for processing residues with a very low copper content. By performing several process steps, the produced copper quality reaches the primary standard and underlines the chemically noble behavior. In addition, significant amounts of other valuable metals such as lead and zinc can selectively be removed from the core process and treated separately.

With regard to electric furnace slag, an approach using pig iron as a reducing agent provides promising results concerning the further cleaning of the fayalite matrix. By lowering the amount of copper and other metals, legislative requirements can potentially be met on a long-term basis. Furthermore, an additional economic benefit could be achieved due to the recovery of the different elements. To sum up, new approaches and technologies will help to determine adequate treatments for a broad variety of residues from the copper industry.

Acknowledgements. The authors want to acknowledge their thanks as the present work was written with the financial help of the Christian Doppler Forschungsgesellschaft, Montanuniversitaet Leoben, and the Austrian government.

Open access funding provided by Montanuniversitaet Leoben.

Open Access This article is distributed under the terms of the Creative Commons Attribution 4.0 International License (http://creativecommons. org/licenses/by/4.0/), which permits unrestricted use, distribution, and reproduction in any medium, provided you give appropriate credit to the original author(s) and the source, provide a link to the Creative Commons license, and indicate if changes were made.

\section{References}

1. Copper Development Association Inc., Annual Data 2016: Copper Supply \& Consumption 1995-2015, https://www.copper.org/ resources/market_data/pdfs/annual_data.pdf (20.09.2016)
2. Schlesinger, M.E.; King, M. J.; Sole, K. C.; Davenport, W. G.: Extractive Metallurgy of Copper, $5^{\text {th }}$ Edition, Elsevier, UK, 2011

3. Lossin, A.: Ullmann's Encyclopedia of Industrial Chemistry: Copper, $7^{\text {th }}$ Edition, Wiley-VCH Verlag $\mathrm{GmbH}, 2007$, pp 1-67

4. U.S. Geological Survey: 2014 Minerals Yearbook: Copper, U.S. Department of the Interior, 2016

5. Reichl, C., Schatz, M.; Zsak, G.: World-Mining Data: Minerals Production, Vienna: BMWFW, 2016

6. Montanwerke Brixlegg: Brixlegg Copper Refinery, http://www. montanwerke-brixlegg.com/en/the-company/brixlegg-copperrefinery/ (19.09.2016)

7. Assarel-Medet JSC: About Assarel-Medet, http://www.asarel.com/ en/About.aspx (19.09.2016)

8. Aurubis Bulgaria: About us, http://bulgaria.aurubis.com/about-us/ (19.09.2016)

9. RTB Rudarsko-topionicarski basen: Bor, Mining and Smelting Combine Bor, http://rtb.rs/en/ (19.09.2016)

10. Kovohuty, a.s.: Welcome to Kovohuty a.s. http://www.kovohuty.sk/ En/index.html (19.09.2016)

11. KGHM Polska Miedz: About Us FP, http://kghm.com/en/about-us (19.09.2016)

12. Langer, B.E., Understanding Copper: Technologies, Markets, Business, Lüneburg : Buchdruck + Offset Walter Wulf, 2011

13. Rentz, O.; Krippner, M.; Hähre, S.; Schultmann, F: Report on Best Available Techniques (BAT) in Copper Production, Berlin, 1999

14. Muchova, L.; Eder, P.; Villanueva, A.: End-of-waste Criteria for Copper and Copper Alloy Scrap: Technical Proposals, European Commission Joint Research Centre, Luxembourg, 2011

15. International Copper Study Group: World Refined Copper Production and Usage Trends, http://www.icsg.org/index.php/component/ jdownloads/finish/165/871 (14.03.2015)

16. Abdel Basir, S. M.; Rabah, M. A.: Hydrometallurgical recovery of metal values from brass melting slag, Hydrometallurgy, (1999) 53 , pp 31-44

17. Ahmed, I. M.; Nayl, A. A.; Daoud, J. A.: Leaching and recovery of zinc and copper from brass slag by sulfuric acid, Journal of Saudi Chemical Society, 2012

18. Guo, J.; Guo, J.; Xu, Z.: Recycling of non-metallic fractions from waste printed circuit boards: A review, Journal of Hazardous Materials, 168 (2009), pp 567-590

19. Maurell-Lopez, S.; Ayhan, M.; Eschen, M.; Friedrich, B.: Autotherme Rückgewinnung aus WEEE-Schrott, Recycling und Rohstoffe, 5 (2012), pp 413-427

20. de Wit, C. A.: An overview of brominated flame retardants in the environment, Chemosphere, 46 (2002), pp 583-624

21. Yamane, L. H.; Tavares de Moraes, V.; Romano Espinosa, D. C. Soares Tenório, J. A.: Recycling of WEEE: Characterization of spent printed circuit boards from mobile phones and computers, Waste Management, 31 (2011), pp 2553-2558

22. Copper Development Association Inc.: The U.S. Copper-base Scrap Industry and its By-products - 2006: Technical Report, http:// www.seas.columbia.edu/earth/RRC/documents/copper\%20scrap \%20report.pdf (14.03.2015)

23. Hugens, J. R.: Future directions for scrap melting in copper shaft furnaces, Recycling and Waste Management, Proceedings of Copper 2013, 2013, pp 309-322

24. Guixa Arderiu, O.; Properzi, P.: Continuous Copper Rod Production from 100 Percent Scrap, Wire journal international, 29, pp 60-67

25. Suping, Y.; Qinghua, L.: Process features and operation practices of NGL furnace in secondary copper smelter, Recycling and Waste Management, Proceedings of Copper 2013, 2013, pp 323-335

26. Rumpold, R.; Antrekowitsch, J.: Strategies to recover the valuable metal fraction from flue dust of the secondary copper production, Schechtman International Symposium, 2014, pp 219-230

27. Hanusch, K.; Bussmann, H.: Behavior and removal of associated metals in the secondary metallurgy of copper, $3^{\text {rd }}$ International symposium on recycling, 1995, pp 171-188, 1995 